\title{
Escitalopram Induced Euprolactinemic Galactorrhoea
}

\author{
Sonali Shinde Tesia', Pakha Tesia², Mahesh R. Gowda3 , Preeti S $^{4}$
}

ÖZET:

Essitalopramın sebep oldug̃u normal prolaktin düzeyi ile giden galaktore

Seçici serotonin gerialım inhibitörleri (SSGi) yaygın olarak reçete edilen antidepresanlardır. Bunlardan essitalopram yan etkilerinin azlıg̃ı sebebi ile en yaygın olarak reçete edilenidir. Biz burada $20 \mathrm{mg} / \mathrm{gün}$ esstilaprom kullanan bir hastada öprolaktinemik galktore olgusu sunuyoruz. Galoktorenin kendisi anksiyete ve depresyonu arttırabilir. Bundan dolayı doktorların essitalopramın galoktoreye sebep olabileceg̃inin farkında olması bir zorunluluktur.

Anahtar sözcükler: essitalopram, galaktore

\section{ABSTRACT:}

Escitalopram

galactorrhoea

Selective serotonin reuptake inhibitors are widely prescribed antidepressants. Among them escitalopram is being widely prescribed because of its minimal adverse effects. Here we report a case of euprolactinemic galactorrhoea due to use of escitalopram $20 \mathrm{mg} /$ day. Galactorrhoea itself may add to coexisting anxiety and depression. Hence it becomes imperative that physicians are aware that escitalopram can cause galactorrhoea.

Key words: escitalopram, galactorrhoea

Journal of Mood Disorders 2012;2(1):15-6
${ }^{1} \mathrm{MD}$, North Eastern Indira Gandhi Regional

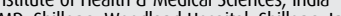

${ }^{3} \mathrm{MD}$, Adichunchanagiri Institute of medical sciences, India ${ }^{4}$ MD
${ }^{4}$, Bellur; P E S Medical College, Kuppam, 'MD,

Yazıșma Adresi / Address reprint requests to: Sonali Shinde Tesia, North Eastern Indira Sonali Shinde Tesia, North Eastern Indira Sciences, India

Elektronik posta adresi / E-mail address: drmaheshspandana@gmail.com

Kabul tarihi / Date of acceptance: 11 Mart 2012 / March 11, 2012

\section{Bag̃ıntı beyanı:}

S.S.T., P.T., M.R.G., P.S.: Yazarlar bu makale ile ilgili olarak herhangi bir çıkar çatıșmas bildirmemișlerdir.

Declaration of interest:

S.S.T., P.T., M.R.G., P.S.: The authors reported no conflict of interest related to this article.

\section{INTRODUCTION}

Escitalopram, a selective serotonin reuptake inhibitor (SSRI) is an S enantiomer of citalopram. It is a widely prescribed antidepressant by both physicians and psychiatrists mainly because of its ease of use and tolerability (1). It acts by inhibiting the serotonin transporter (SERT) and increasing the levels of serotonin in the synapse. Gastrointestinal adverse effects have been reported commonly (10-15\%) with escitalopram. Other adverse effects include insomnia, dizziness, fatigue, lethargy, decreased libido, etc (2). Endocrine and reproductive side effects are very uncommon among the SSRIs (3). Here we report a case of euprolactinemic galactorrhoea associated with escitalopram use.

\section{CASE}

A 43 year old married lady came with complaints of sad mood, aches and pains all over the body and decreased sleep for 2 months. She was diagnosed major depressive disorder according to ICD - 10 . She was prescribed tablet escitalopram $5 \mathrm{mg}$ to be taken once a day. The dose was gradually increased to $10 \mathrm{mg}$ and later to $20 \mathrm{mg}$ / day over a period of two months, as she had partial improvement with the lower doses. Since she was feeling better during regular monthly follow ups, the dose of $20 \mathrm{mg} /$ day was continued. After 6 months, she complained of galactorrhoea and dull ache and fullness in breasts, which was embarrassing in social situations for one month. There was no past history or family history of any breast related illness, nor was she on any other medication. Her physical examination did not reveal anything abnormal. Serum prolactin was found to be $5.40 \mathrm{ng} / \mathrm{ml}$ (normal range 2.8-29.2ng/ml). Her hemogram, liver function tests, kidney function tests, FSH, LH, prolactin, and thyroid function tests were within normal limits. A diagnosis of escitalopram induced galactorrhoea was made. Hence, the dose of escitalopram was gradually tapered to $5 \mathrm{mg}$ and later stopped. Galactorrhoea and other breast related symptoms subsided with a decrease in dose and then disappeared on stopping the drug. She was then prescribed 
tablet mirtazapine $7.5 \mathrm{mg} /$ day and has been doing well since then.

\section{DISCUSSION}

Escitalopram is a well-tolerated SSRI and is rarely associated with any serious side effect. Endocrine and reproductive side effects are very uncommon among the serotonergic antidepressants (3). Here, we report a case of euprolactinemic galactorrhoea induced by escitalopram. In this case, we attribute galactorrhoea to be due to escitalopram as there were no other detectable causes for galactorrhoea and moreover the symptoms subsided with a reduction in dosage and completely disappeared after stopping the drug. As per causality assessment escitalopram as a causative agent for galactorrhoea can be considered to be probable (Naranjo s algorithm =7) (4).

There have been a few reports of hyperprolactinemic galactorrhoea with escitalopram wherein the possible mechanism postulated was serotonin $(5 \mathrm{HT})$ mediated inhibition of tuberoinfundibular dopaminergic neurons leading to an elevated prolactin level or direct stimulation of prolactin release by postsynaptic $5 \mathrm{HT}$ receptors situated in the hypothalamus $(5,6)$.

But in the present case, prolactin levels were within the normal range. The authors could find only two such cases $(7,8)$. In the present report, galactorrhoea was seen at a dose of $20 \mathrm{mg}$ of escitalopram as reported by Gulsun et al.,

\section{References:}

1. De Ballista C. Antidepressant agents. In basic and clinical pharmacology. Katzung BG, Masters SB, Trevor AJ, eds. $11^{\text {th }}$ ed. New Delhi: Tata McGraw Hill, 2009;509-30.

2. Keltner NL, Folks DG. Psychotropic drugs. $4^{\text {th }}$ ed. New York: Elsevier publication, 2005; 652-53.

3. Aggarwal A, Kumar R, Sharma RC, and Sharma DD. Escitalopram induced galactorrhoea: Acase report. Progress in NeuroPsychopharmacology\& Biological Psychiatry 2010; 34:557-58.

4. Naranjo CA, Busto U, Sellers EM, Sandor P, Ruiz I, Roberts EA et al. A method for estimating the probability of adverse drug reactions. Clin Pharmacol Ther 1981; 30:239-45.

5. Shim SH, Lee YJ, Lee EC. A case of galactorrhoea associated with escitalopram. Psychiatry Investig 2009;6: 230-32. but in this patient galactorrhoea was seen after 6 months after starting the drug. It has been suggested that TRH hyper responsiveness could be responsible for galactorrhoea with normal prolactin levels. Though thyroid function tests were within normal limits in this patient, sensitivity of TRH could have added further information (9).

The patient was then switched over to tablet mirtazapine $7.5 \mathrm{mg}$ per day with which the patient improved and did not have any complaints of galactorrhoea. Mirtazapine is a tetracyclic antidepressant which blocks presynaptic $\alpha_{2}$ receptors and enhances the release of norepinephrine and serotonin. It is also an antagonist at $5 \mathrm{HT}_{2}$ and $5 \mathrm{HT}_{3}$ receptors. This suggests that there is a possible novel mechanism for galactorrhoea induced by escitalopram (10).

Galactorrhoea induced by escitalopram can be managed by switching over to other antidepressants like dothiepin, nefazodone, bupropion, which are less likely to cause hyperprolactinemia (11). In conclusion, clinicians should be aware of galactorrhoea as a possible adverse effect with escitalopram. In postmenopausal women galactorrhoea itself can lead to significant anxiety and depression. Hence it may be necessary to reduce the dose or switch over to another antidepressant rather than increasing the dosage. Further research is required to better understand the mechanisms of actions and adverse events of SSRIs including escitalopram.
6. Gulsun M, Evrensel A, Verim S. Galactorrhea during escitalopram treatment: a case report. Bull Clin Psychopharmacol 2006;16:3941.

7. Gulsun M, Algul A, Semiz UB, Ates MA, Doruk A, Ebrinc S, et al. A case with euprolactinemic galactorrhea induced by escitalopram. Int J Psychiatry Med 2007; 37:275-78.

8. Egberts AC, Meyboom RH, DeKoning FH, Bakker A, Leufkens HG. Non-puerperal lactation associated with antidepressant drug use. Br J Clin Pharmacol 1997; 44:277-81.

9. Ataya KM,SubramanianMG,LawsonDM,GalaRR.Euprolactinemic galactorrhoea. Response of bioassayable prolactin to thyrotropin releasing hormone. J Reprod Med 1996;41:156-60. 